\title{
Evaluation of Carbon Sequestration and Global Warming Potential of Wheat in Khorasan-Razavi Province
}

\author{
Surur Khorramdel ${ }^{1 *}$, Javad Shabahang ${ }^{1}$, Raheleh Ahmadzadeh Ghavidel ${ }^{1}$, Abdollah Mollafilabi ${ }^{2}$
}

\author{
College of Agriculture, Ferdowsi University of Mashhad, Iran \\ Research Institute of Food Science and Technology, Mashhad, Iran \\ *Email: khorramdel@um.ac.ir
}

Submission: September 16 ${ }^{\text {th }}, 2017$; Acceptance: August 31 ${ }^{\text {th }}, 2018$

\begin{abstract}
In order to determine soil characteristics and above-ground and below-ground carbon sequestration potential of wheat, a systematic random sampling method was employed to select 5 samples from 50 fields situated in Khorasan-Razavi Province, Iran during 2015. The experimental design was a completely randomized design with three replications. The ash method was used to determine the carbon sequestration conversion coefficients in spikes, stems, leaves and roots. Then, greenhouse gases (such as $\mathrm{CO}_{2}, \mathrm{~N}_{2} \mathrm{O}$ and $\mathrm{CH}_{4}$ ) emission were calculated using emission coefficients. The average organic carbon, total nitrogen, available phosphorus, available potassium, soil bulk density, pH and electrical conductivity were found to be $0.98 \%, 0.02 \%, 27.07 \mathrm{ppm}, 341.32 \mathrm{ppm}, 1.37$ g.cm-3, 7.81 and $1.42 \mathrm{dS} . \mathrm{m}^{-1}$, respectively. The maximum (52.0\%) and minimum (31.99\%) conversion coefficients were related to spikes (seeds included) and roots, respectively. In addition, the total carbon sequestration was 8.25 t.ha $^{-1}$ so that the maximum $\left(4.28\right.$ t.ha $\left.^{-1}\right)$ and minimum $\left(0.35 \mathrm{t}^{-h a^{-1}}\right)$ values were found in stems and roots, respectively. The total global warming potential (GWP) of wheat was recorded as $2377.86 \mathrm{~kg} \mathrm{CO}_{2}$-equiv. per ton of seed. The first contributing factor was nitrogen fertilizers, accounting for $1331.30 \mathrm{~kg} \mathrm{CO}_{2}$-equiv. per ton of seed.
\end{abstract}

Keywords: Ash method; conversion coefficient; nitrogen fertilizer; spike

\section{Introduction}

Atmospheric carbon dioxide concentration has increased by $25 \%$ since late $18^{\text {th }}$ century. The conventional management of agroecosystems, intensive tillage and fossil fuels as well as converting pastures to drylands, deforestation and burning crop residue are among the most effective factors in increasing atmospheric carbon dioxide concentration (Hutchinson et al., 2007). It has been reported that agricultural land contributes about $20-25 \%$ of total carbon dioxide released into the atmosphere (Duxbury et al., 1993). There are several ecological solutions helping agroecosystems to reduce carbon dioxide emission into atmosphere, for example zero tillage systems (Follett et al., 2005), organic fertilizers (Falloon et al., 1998), crop rotation (Follett et al., 2005) and intercropping (Follett et al., 2005) are the most important approaches.
Carbon sequestration is the most efficient and environmentally safe approach for entering carbon dioxide into the soil in the form of organic matter. Soil is the largest terrestrial carbon source so soil carbon sequestration management can positively impact soil carbon stocks (Ingram and Fernandez, 2001). It has been reported that carbon stock in unploughed soils is 67-512 kg.ha-1 higher than ploughed soils (Unploughed soils). No tillage and crop residue retention increase carbone sequestration potential in agricultural land (Yan et al., 2007). In a study, (Khorramdel et al., 2013) have stated that intensive tillage and nitrogenous chemical fertilizers increased decomposition rate organic carbon of and decreased carbon sequestration potential. Accordingly, considering the low organic matter content of soil in arid and semi-arid regions of the world (Bationo and Buerkert, 2001), increase in soil organic matter 
Table 1. Consumed inputs in wheat agrosystems per ton of seed in Khorasan-Razavi during 2014 ₹2015

\begin{tabular}{|c|c|c|c|c|c|c|c|}
\hline \multirow{2}{*}{ Manure (ton) } & \multirow{2}{*}{ Insecticide (I) } & \multirow{2}{*}{ Fungicide (I) } & \multirow{2}{*}{ Herbicide (I) } & \multicolumn{3}{|c|}{ Chemical fertilizers $(\mathrm{kg})$} & \multirow{2}{*}{ Fuel (I) } \\
\hline & & & & $\mathrm{K}$ & $\mathrm{P}$ & $\mathrm{N}$ & \\
\hline 0.78 & 0.31 & 0.42 & 2.13 & 36.98 & 158.14 & 253.45 & 8862.56 \\
\hline
\end{tabular}

could be a multi-purpose solution to reduce atmospheric carbon dioxide and to improve carbon sequestration potential to achieve sustainability in agroecosystems. Native plants and dominant crops play a key role in carbon sequestration (Hill et al., 2003). Species, adapted to arid and semi-arid regions, involve in carbon sequestration in different ways. It has been found that there is a significant relationship between vegetation carbon stock and carbon sequestration rate (NajmEldini, 2013). Carbon sequestration potential depends on species, climate conditions and land management techniques (Mortenson and Schuman, 2002). In a study on perennial millet (Ma, 1999) have found that the role of roots in carbon sequestration is much more than other tissues.

With special climate conditions, Iran has provided a suitable platform for the production of agricultural products. In the meantime, cereal production is the major determinant of agricultural goods. Nonetheless, there are major water restrictions in crop production in semi-arid areas such as Khorasan-Razavi, where farming depends on irrigation. Drought-tolerant cereals, especially wheat which is considered as a strategic species, have great importance in these areas. Although there are various approaches to improve carbon sequestration potential, a significant part of the land in Khorasan-Razavi production area is located in arid and semi-arid regions where organic matter content is considerably low $(<0.1 \%)$ for lack of vegetation and high oxidation rates (Hajabbasi and Hemmat, 2000; Mosaddeghi etal., 2000; Shirani etal., 2002). Accordingly, evaluating carbon sequestration potential in different tissues of wheat, as one of the most important crops in the region, is not only necessary, it is essential for its sustainable production. Moreover, determining the soil characteristics of this valuable product and assessing its global warming potential (GWP) would help to better management of natural resources. Therefore, the current study was aimed to evaluate soil characteristics, determine carbon sequestration potential in aboveground and below-ground tissues of wheat and assess GWP in Khorasan-Razavi Province.

\section{Material and methods}

\section{Carbon sequestration potential}

A systematic random sampling method (Chambers and Brown, 1983) was employed to select 5 samples from 50 fields situated in Khorasan-Razavi Province, Iran during 2015. Roots were collected from $0-30$ $\mathrm{cm}$ depth (Mahdavi et al., 2009). The sampling was done using transects (three $100 \mathrm{~m}$ ), each measuring $50 \times 50 \mathrm{~cm}$ plots. All above-ground and below-ground tissues were collected from each plot. The vegetative (including stems, leaves and roots) and reproductive (spikes including seeds) tissues were collected in spring. Soil samples were randomly taken from five plots in each transect. Sampling was performed just under the plants at the depth of $0-30 \mathrm{~cm}$. The ash method was used to determine the carbon sequestration conversion coefficients in spikes, stems, leaves and roots (Abdi et al., 2008; Bordbar et al., 2008; Forouzeh et al., 2008). For this purpose, the weighted samples were oven dried for $24 \mathrm{~h}$ at $60{ }^{\circ} \mathrm{C}$ and then burned for 3 hr at $500{ }^{\circ} \mathrm{C}$. The ash samples were cooled down in a desiccator before weighting (Polidori et al., 2008). Soil carbon sequestration was calculated after determining soil organic carbon (Walkley and Black, 1934) and soil bulk density (Black, 1965) using Nosetto et al., 2006) equation.

\section{Greenhouse gas emission and GWP}

In order to assess greenhouse gas emissions and GWP a questionnaire method (50 questionnaires) was used to collect detailed information on fuel consumption, organic (cattle manure) and mineral fertilizers ( $\mathrm{N}, \mathrm{P}$ and $\mathrm{K}$ ), herbicides and pesticides. The number of questionnaires was determined according to Snedecor and Cochran (1980). The average input consumption amount in Khorasan-Razavi is shown in Table 1. Greenhouse gases (such as $\mathrm{CO}_{2}, \mathrm{~N}_{2} \mathrm{O}$ and $\mathrm{CH}_{4}$ ) emission was calculated using emission coefficients (IPCC, 2007; Snyder et al., 2009; Tzilivakis et al., 2005; Lal, 2004). It should be noted that due to lack of CO2 emission coefficient for pesticides and low application in most of the fields, this parameter was not assessed. In this regard, it has been reported that pesticides have a negligible effect on GWP (Khoshnevisan et al., 2013). 
Since greenhouse gases affect GWP in different ways (IPCC, 2007), so the index was calculated based on $\mathrm{CO} 2$ using the following equation (Tzilivakis et al., 2005).

$\mathrm{GWP}=\mathrm{CO}_{2}$ flux $+\left(\mathrm{N}_{2} \mathrm{O}\right.$ flux $\left.\times 310\right)+\left(\mathrm{CH}_{4}\right.$ flux $\left.\times 21\right)$

Where GWP is global warming potential $\left(\mathrm{kg} \mathrm{CO}_{2}\right.$-equiv. per ton of seed), $\mathrm{CO}_{2}$ flux is carbon dioxide emission, $\mathrm{N}_{2} \mathrm{O}$ flux is nitrogen oxide emission and $\mathrm{CH}_{4}$ flux is methane emission.

Questionnaire's reliability was evaluated using the Cronbach's Alpha method (Cronbach, 1951). The data on carbon sequestration potential were analysed in a completely randomized design using SAS 9.1. Collected samples were considered as replications. The means were compared by LSD test and graph was plotted in Excel.

\section{Results}

Questionnaire's reliability ( $a=84 \%$ ) was found to be satisfactory using the Cronbach's Alpha method.

\section{Soil physical and chemical properties}

The soil texture was found to be clay loam. The average organic carbon, total nitrogen, available

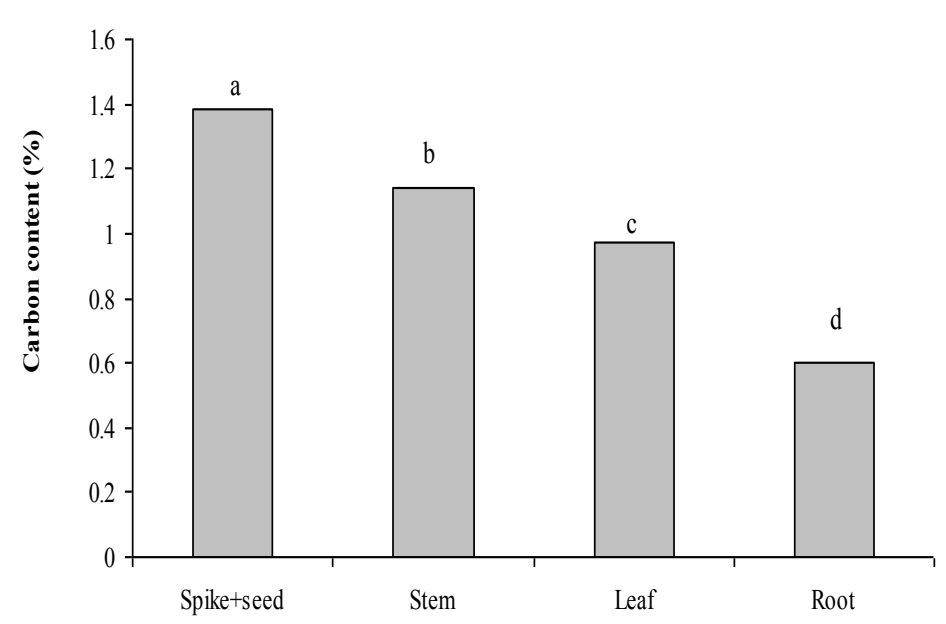

(A) phosphorus, available potassium, bulk density, $\mathrm{pH}$ and EC of soil were found to be $0.98 \%, 0.02 \%, 27.07$ ppm, $341.32 \mathrm{ppm}, 1.37 \mathrm{~g} . \mathrm{cm}^{-3}, 7.81$ and $1.42 \mathrm{dS} . \mathrm{m}^{-1}$, respectively.

\section{Above-ground and below-ground tissues yield}

The average yields for spikes+ seeds, stem, leaves and roots of wheat were recorded as 509.16, 880.64, 236.97 and $109.73 \mathrm{~g} . \mathrm{m}^{-2}$, respectively.

\section{Carbon sequestration potential conversion coefficients}

There was significant difference between aboveground and below-ground tissues in terms of carbon content and conversion coefficients (Table 2). The maximum $(1.39 \%)$ and minimum $(0.60 \%)$ carbon content were related to spikes (seed included) and roots, respectively. Carbon content increased by 91 and $62 \%$ in stems and leaves, respectively compared with the roots. Increase in above-ground carbon content was $95 \%$ higher than that in the roots (Figure $1 \mathrm{~A}$ ). The maximum conversion coefficient (52.0\%) was observed in spikes, whereas the minimum value $(31.99 \%)$ was related to the roots. Conversion coefficient increased by

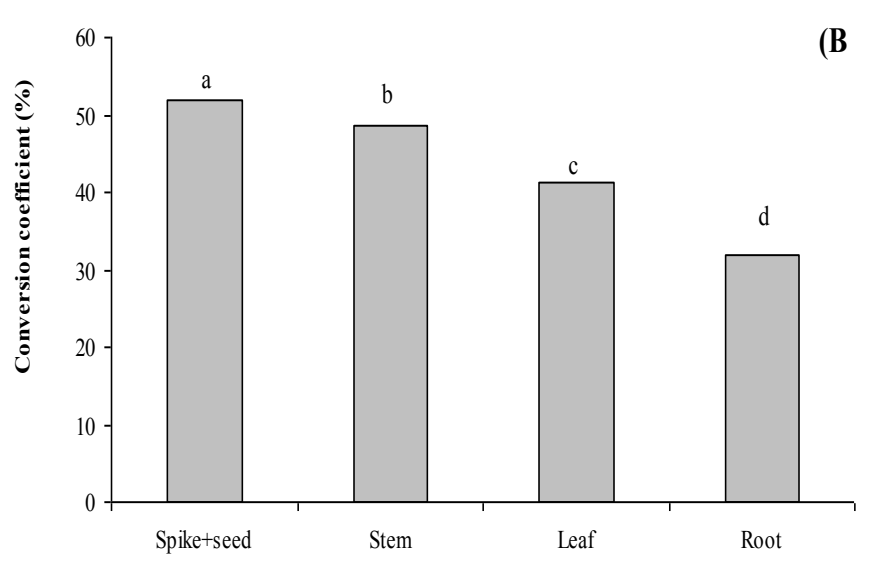

(B)

Means with different letter(s) in each have significant difference based on Duncan's test ( $p \leq 0.05)$.

Figure 1. Mean comparison for (A) carbon content and (B) conversion coefficients of wheat above-ground and below-ground tissues

Table 2. Analysis of variance (mean of squares) on carbon content, conversion coefficients and carbon sequestration potential as affcted by wheat above-ground and below-ground tissues

\begin{tabular}{ccccc}
\hline Carbon sequestration potential & Conversion coefficient & Carbon content & $\mathrm{df}$ & S.O.V. \\
\hline $155654^{* *}$ & $391.05^{* *}$ & $0.548^{* *}$ & 3 & Above-ground and below-ground tissues \\
112 & 4.63 & 0.00282 & 16 & Error \\
- & & - & 19 & Total \\
\hline
\end{tabular}

**: Significant at $1 \%$ probability level 
52 and $29 \%$ in stems and leaves, respectively compared with the roots. Furthermore, above-ground tissues average conversion coefficient was $48 \%$ higher than the roots (Figure 1B).

Carbon sequestration potential significantly affected by plants tissues (Table 2). The total carbon sequestration was 8.25 t.ha $^{-1}$ so that the maximum (4.28 t.ha $^{-1}$ ) and minimum ( 0.35 t.ha $^{-1}$ ) values were found in stems and roots, respectively. Stems, spikes, leaves and roots accounted for 52, 32, 12 and 4\% of the total carbon sequestration, respectively (Table 2 ).

\section{Global warming potential (GWP)}

The total GWP of wheat was recorded as 2377.86 $\mathrm{kg} \mathrm{CO} 2$-equiv. per ton of seed. The first contributing factor was nitrogenous fertilizers, accounting for $1331.30 \mathrm{~kg} \mathrm{CO}$-equiv. per ton of seed. Among applied mineral fertilizers, the minimum greenhouse gas emission (194.24 $\mathrm{kg} \mathrm{CO}_{2}$-equiv. per ton of seed) was related to $\mathrm{K}$ fertilizers. As to $\mathrm{P}$ fertilizers, there was $38 \%$ less emission compared with nitrogenous fertilizer. The maximum and minimum greenhouse gas emission were related to herbicides $(13.86 \mathrm{~kg} \mathrm{CO} 2$-equiv. per ton of seed) and fungicides ( $7.80 \mathrm{~kg} \mathrm{CO} 2$-equiv. per ton of seed), respectively (Figure 3 ).

\section{Discussion}

The soil carbon sequestration was found to be $4027.80 \mathrm{~g} \cdot \mathrm{m}^{-2}$. Low organic matter content in soil may be the reason why the soil carbon sequestration is low. The soil carbon sequestration potential in canola fields in Khorasan-Razavi has been reported as 3.46 t.ha${ }^{1}$ (Khorramdel et al., 2015). Planting legumes in crop rotation not only improves soil nitrogen content, but increases soil carbone stocks (Melero et al., 2011). It has been confirmed that in any system where carbon input is greater than carbon output, carbon sequestration will occur (Jastrow et al., 2007). In addition, increase in carbon sequestration ( $57 \pm 14 \mathrm{~g} \cdot \mathrm{m}^{-2}$ per year) through

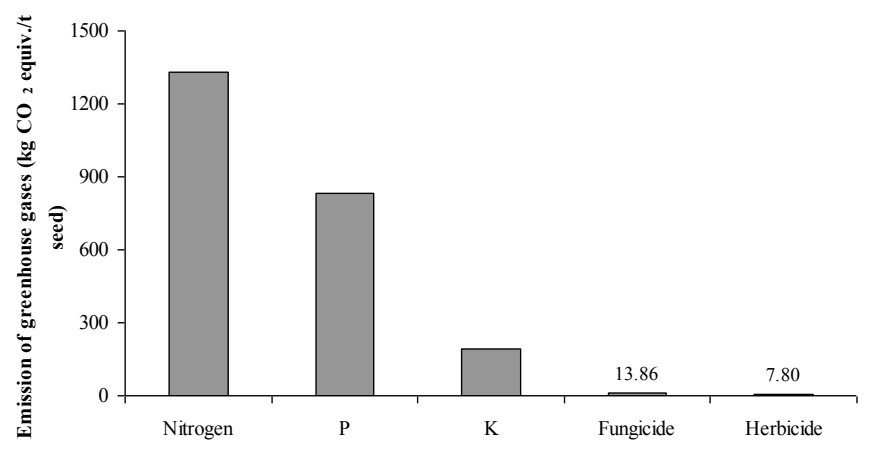

Fig. 3-Total green house gases emissions for wheat agroecosystems in Khorasan-Razavi based on consumed inputs shifting from conventional tillage to zero tillage was reported by (West and Post, 2002) who stated that crop rotation increases carbon sequestration by $0.15 \pm$ $0.11 \mathrm{Mg}$ ha $^{-1}$ per year. Returning crop residue into the soil increase carbon sequestration rate (Havlin et al., 1990) and improve soil structure (Lal, 1997) through increasing soil organic carbon content. It has been well documented that carbon sequestration is affected by cropping systems (monoculture or intercropping) and soil organic matter management (Schulp et al., 2008). Perennial plants produce more woody tissues (Nobakht et al., 2011; Tamartash et al., 2012) and need less soil tillage (Jastrow et al., 2007; West and Post, 2002) and can be in rotation with legumes (López-Bellido et al., 2010) have great impact on soil organic matter content and carbon sequestration (Campbell et al., 1996a; Campbell et al., 1996b; López-Bellido et al., 2010). Accordingly, taking advantages of new tillage practices such as minimum tillage or zero tillage, returning crop residue into the soil and planting legumes in rotation are highly recommended to increase soil carbon sequestration potential and to get closer towards sustainable wheat production, especially in arid and semi-arid regions.

Reduction in leaves and roots conversion coefficients might be due to higher concentration of minerals in these tissues. On the other hand, higher conversion coefficient in spikes is mainly caused by lower water content in these tissues. The higher conversion coefficient in above-ground tissues compared with underground tissues has been previously reported by (Jafarian and Tayefeh Seyyed Alikhani, 2013).

In a study comparing above-ground and belowground tissues of canola the maximum conversion coefficient $(51.65 \%)$ was related to siliques. The conversion coefficients for stems, leaves and roots were found to be 5, 16 and 34\% less than siliques (Khorramdel et al., 2015). Significant differences between Cistus species, dendrostellera (Dendrostellera lessertii) and camel grass (Artemisia deserti) in terms of conversion coefficients were found by Forouzeh et al. (2008).

Although, roots contain more lignin than stems, root exudates (Daudu et al., 2009) and lower C to $\mathrm{N}$ ratio (Russell et al., 2005) may be considered as the main reason for reduced carbon sequestration potential in roots compared with stems. On the other hand, lignin accumulation in stems and also higher dry weight in comparison with other tissues increases carbon sequestration potential. Therefore, it seems that lignified tissues are more able to sequestrate carbon. Accordingly, considering the significance of agriculture in increasing greenhouse gas emission, it is highly recommended to plant perennial species such as forage crops and medicinal plants, as well as to reduce the 
conventional tillage practices and optimum use of organic fertilizers to mitigate global warming potential (Braschkat et al., 2003). Taking advantages of these environmentally safe techniques not only reduces soil erosion but also improve carbon sequestration potential and promotes agroecosystems stability. In addition, in order to make the results more applicable, returning wheat residues as a by-product into the soil, especially in arid and semi-arid regions of Khorasan-Razavi Province, is recommended to improve soil organic matter and carbon sequestration potential. As mentioned before, the total carbon sequestration potential for canola was 5.12 t.ha $^{-1}$ (Khorramdel et al., 2015), and stems and leaves accounted for 1.81 and 0.76 t.ha $^{-1}$, respectively. Carbon sequestration potential for silique and root were found to be 4 and $56 \%$ less than stem. In a study the maximum (10.02 t.ha-1) and minimum (0.18 t.ha$\left.{ }^{1}\right)$ carbon sequestration potential were found in spikes and roots, respectively (Jafarian and Tayefeh Seyyed Alikhani, 2013). Singh et al. (2003) have reported that carbon sequestration potential varies in aboveground and below-ground tissues. In addition, it has been reported that above-ground carbon sequestration potential is higher than that in below-ground tissues (Gao et al., 2007; Yong, 2007).

Taking together, considering the low organic matter content in soil (Hajabbasi, and Hemmat, 2000; Mc Conkey et al., 2003; Mosaddeghi et al., 2000) and positive effect of crop residues on soil physical, chemical and biological properties (Kirchmann et al., 2016; Busari et al., 2015), it is recommend to return wheat residues into the soil to increase soil organic matter especially in arid and semi-arid regions of Khorasan-Razavi fields. Improving soil carbon sequestration potential results in increased crops biomass, enhanced soil fertility and greater soil water retention capacity, which in turn reduce soil degradation and erosion (Jafarian and Tayefeh Seyyed Alikhani, 2013). Therefore, any measure that increases vegetation growth rate would be predicted to improve carbon sequestration potential.

In agroecosystems, fossil fuels and nitrogenous fertilizers are the main sources for greenhouse gases (mainly $\mathrm{CO}_{2}$ and $\mathrm{N}_{2} \mathrm{O}$ ) emission. It has been reported that $59 \%$ of $\mathrm{CO} 2$ emission is caused by nitrogenous fertilizers manufactures (Brentrup et al., 2004). In addition, 14\% of $\mathrm{CO}_{2}$ emission in agroecosystems has been attributed to soil tillage (Cooper et al., 2011). Therefore, in order to mitigate $\mathrm{CO}_{2}$ emission from agroecosystems minimum tillage techniques should be taken into account. Carbon dioxide emission due to herbicides application has been estimated as $1996-2000 \mathrm{~kg} \mathrm{CO}_{2}$-equiv. per each active component (Nagy, 2000). In addition to increasing the concentration of carbon dioxide during the past centuries due to industrial development, increase in $\mathrm{N}_{2} \mathrm{O}$ from 275 to $319 \mathrm{ppm}$ is going to be a great concern. Although the $\mathrm{N}_{2} \mathrm{O}$ concentration in the atmosphere is quite low, its GWP is 310 times more than $\mathrm{CO}_{2}$, in addition, it is harmful to the ozone layer (Crutzen, 1981). According to IPCC, nitrogen emission into atmosphere is equal to $1.25 \mathrm{~kg} \mathrm{~N} 2 \mathrm{O}$-eqiuv. per $100 \mathrm{~kg}$ (ISO, 2006). Brentrup et al. (2004) believed that $\mathrm{N}_{2} \mathrm{O}$ emission directly depends on chemical fertilizers production and application. Similarly, Bouwman (1990) has introduced extensive use of chemical fertilizers and tillage as the main reason for $\mathrm{N}_{2} \mathrm{O}$ emission from agroecosystems. The maximum GWP for irrigated wheat $\left(889.61 \mathrm{~kg} \mathrm{CO}_{2}\right.$-equiv. per ton of seed) was related to $220 \mathrm{~kg} \cdot \mathrm{ha}^{-1}$ nitrogen application. The value was recorded as $937.73 \mathrm{~kg} \mathrm{CO}_{2}$-equiv. per ton of seed for rain-fed wheat when $60 \mathrm{~kg} \mathrm{ha}^{-1}$ nitrogen was applied (Khorramdel et al., 2014). It has been stated that the annual $\mathrm{N}_{2} \mathrm{O}$ emission for wheat field in Germany as affected by tillage and chemical fertilizers application is 0.2-0.27 kg of $\mathrm{N}_{2} \mathrm{O}$ per ha-1 (Barker-Reid et al., 2005). Meisterling et al. (2009) indicated that organic cropping systems produced $30 \mathrm{~kg}$ less $\mathrm{CO}_{2}$ than conventional cropping systems to produce $1 \mathrm{~kg}$ of bread. Similar results have been found by Moudrý et al. (2013). Thus, although nitrogenous fertilizers increase seed yield, it should be kept in mid that excessive use of chemical fertilizers not only increases production cost and energy consumption, but also increases greenhouse gases emission during production process. As mentioned earlier greenhouse gases emission amount depends on management and climate conditions (Khan et al., 2009; Khan et al., 2010), therefore, it can be suggested that taking account of sustainable approaches such as conservation tillage, organic fertilizer application and having legumes in crop rotation systems would appreciably improve agroecosystems sustainability (Braschkat et al., 2003). New methods including conservation tillage (minimum tillage or zero tillage) not only save more energy, but also prevent soil erosion through increasing soil organic matter content and enhance carbon sequestration potential. The development of agricultural technologies has led to an increase in energy consumption, which in turn has led to an increase in environmental pollution principally due to release various pollutants into different ecosystems in the form of leaching, evaporation, sublimation, etc., resulting in different health issues (Skowroñska and Filipek, 2014). Generally, during 2011 and 2012 over 15 million ton chemical fertilizer (in the form of urea, $\mathrm{P}_{2} \mathrm{O}_{5}$ and $\mathrm{K}_{2} \mathrm{O}$ ) were used in Europe. These amount of fertilizers produced 1.6 ton $\mathrm{CO}_{2}$ per each ton of $\mathrm{NH}_{3}$ and released 2-2.5 ton of $\mathrm{N}_{2} \mathrm{O}$ per each ton of $\mathrm{HNO}_{3}$ (Skowroñska and Filipek, 2014). During chemical fertilizer production $3-10 \% \quad \mathrm{~N}_{2}$ and $0.3-3 \%$ 
$\mathrm{NH}_{4}$ are release into the atmosphere. Difference in soil moisture content in different agroecosystems increases $\mathrm{N}_{2} \mathrm{O}$ and nitrate leaching (Brentrup and Palliere, 2008; Lammel, 2000). Therefore, it is suggested that the environmental status of these production systems should be investigated using various ecological approaches such as life cycle assessment. In this regard, Brentrup et al. (2004) have stated that evaluating stability of production systems is essential. They have emphasized that LCA could solve agroecosystems problems such as input consumption and land use change. Similarly, Eckert et al. (1999) have pointed out to the same approach. Furthermore, as these approaches compare the environmental performance in different production systems, thus, following these approaches would help to introduce the most appropriate systems to reduce pollution and to optimize input use by applying more precise amounts of fertilizer and other chemicals at the optimal time.

\section{Conclusion}

The obtained results demonstrated that carbon sequestration in wheat fields located in Khorasan-Razavi Province is very low, which can be attributed to low soil organic matter content. There was a significant difference between above-ground and below-ground tissues in terms of carbon sequestration potential and conversion coefficient. Accordingly, it is highly recommended that sustainable measures such as returning the crop residues into the soil should be put in place to improve soil physical, chemical and biological properties and also carbon sequestration potential, especially in arid and semi-arid regions, where organic matter oxidation rate is high. Furthermore, as nitrogenous fertilizer application plays a crucial role in increasing GWP, thus it is suggested that organic fertilizers and legumes might be a suitable alternative for chemical fertilizers. Last but not least, it is suggested that the status of agroecosystems is examined using various ecological approaches such as life cycle assessment.

\section{References}

Abdi, N., Maadah Arefi, H. and Zahedi Amiri, G. 2008. Estimation of carbon sequestration in Astragalus rangelands of Markazi province (case study: Malmir rangeland in Shazand region). Iranian Journal of Range Desert Research 15(2): 269-282. (in Persian with English Summary)

Barker-Reid, F., Gates, W.P., Wilson, K., Baigent, R., Galbally, I.E., Meyer, C.P., Weeks, I.A. and Eckard, R.J. 2005. Soil nitrous oxide emission from rainfed wheat in SE Australia. In: A. van Amsted (Ed.). Non-CO2 greenhouse gases (NCGG-4). Utrecht, the Netherlands: Millpress.
Bationo, A. and Buerkert, A. 2001. Soil organicc arbon management for sustainable land use in SudanoSahelian West Africa. Nutrient Cycling in Agroecosystems 61: 131-142.

Black, C.A. 1965. Methods of Soil Analysis. (V. I). American Society of Agronomy. 1572 pp.

Bordbar, S.K. and Mortazavi Jahromi, S.M. 2008. Carbon sequestration potential of Eucalyptus camaldulensis Dehnh. and Acacia salicina Lindl. plantation in western areas of Fars province. Pajouhesh Sazandegi (70): 95103. (in Persian with English Summary)

Bouwman, A.F. 1990. Exchange of greenhouse gases between terrestrial ecosystems and the atmosphere. In: A.F. Bouwman (Ed.), Soils and the greenhouse effect (pp. 61-127). Chichester: Wiley.

Braschkat, J., Patyk, A., Quirin, M., and Reinhardt, G.A. 2003. Life cycle assessment of bread production-a comparison of eight different scenarios. In: Proceedings of the Fourth International Conference on Life Cycle Assessment in the Agri-Food Sector, October 6-8, Bygholm, Denmark. p. 9-16.

Brentrup F., Kusters J., Kuhlmann H. and Lammel J. 2004. Environmental impacts assessment of agricultural production systems using the life cycle assessment methodology, I. Theorical concept of a LCA method tailored to crop production. European Journal of Agronomy 20: 247-264.

Brentrup, F. and Palliere, C. 2008. GHG emissions and energy efficiency in European nitrogen fertiliser production and use. Proc. International Fertiliser Society, December 11, York, UK.

Busari, M.A., Kukal, S.S., Kaur, A., Bhatt, R. and Dulazi, A.A. 2015. Conservation tillage impacts on soil, crop and the environment. International Soil and Water Conservation Research 3(2): 119-129.

Campbell, C.A., Mc Conkey, B.G., Zentner, R.P., Selles, F. and Curtin, D. 1996a. Long-term effects of tillage and crop rotations on soil organic $\mathrm{C}$ and total $\mathrm{N}$ in a clay soil in southwestern Saskatchewan. Canadian Journal of Soil Science 76: 395-401.

Campbell, C.A., Mc Conkey, B.G., Zentner, R.P., Selles, F. and Curtin, D. 1996b. Tillage and crop rotation effects on soil organic $\mathrm{C}$ and $\mathrm{N}$ in a coarse-textured Typic Haploboroll in southwestern Saskatchewan. Soil and Tillage Research 37: 3-14.

Chambers, J.C. and Brown, R.E. 1983. Methods for Vegetation Sampling and Analysis on Revegetated Mined Lands. Intermountain Forest and Range Experiment Station. General Technical Report. International.

Cooper, J.M., Butler, G. and Leifert, C. 2011. Life cycle analysis of greenhouse gas emissions from organic and conventional food production systems, with and without 
bio-energy options. NJAS Wageningen. Journal of Life Science 58: 185-192.

Cronbach, L.J. 1951. Coefficient alpha and the internal structure of tests. Psychometrika 16(3): 297-334.

Crutzen, P.J. 1981. Atmospheric chemical processes of the oxides of nitrogen, including nitrous oxide. In: C.C. Delwiche (Ed.), Denitrification, nitrification, and atmospheric nitrous oxide (pp. 17-44). New York: Wiley.

Daudu, C.K., Muchaonyerwa, P. and Mnkeni, P.N.S. 2009. Litterbag decomposition of genetically modified maize residues and their constituent Bacillus thuringiensis protein (Cry1Ab) under field conditions in the central region of the Eastern Cape, South Africa. Agriculture, Ecosystems and Environment 134: 153-158.

Duxbury, J.M., Harper, L.A. and Moiser, A.R. 1993. Contributions of agroecosystems to global climate change. (Eds. Harper, L., Duxbury, J.M., Moiser, A.R., and Rolstonj, D.S.) In: "Agroecosystems effects on radioactively important trace gases and global climate change". ASA Publications, No. 55. American Society of Agronomy, Madison, Wisconsin, pp. 1-18.

Eckert H., Breitschuh G. and Sauerbeck D. 1999. Kriterien einer umweltverträglichen Landbewirtschaftung (KUL)-ein Verfahren zur ökologischen Bewertung von Landwirtschaftsbetrieben (Criteria of Environmentally friendly land use (KUL) - a method for the environmental evaluation of farms). Agriculture Biotechnology Research 52: 57-76. (In German)

Falloon, P.D., Smith1, P., Smith, J.U., Szabó, J., Coleman, K. and Marshall, S. 1998. Regional estimates of carbon sequestration potential: linking the Rothamsted Carbon Model to GIS databases. Biology and Fertility of Soils 27(3): 236-241.

Follett R.F., Castellanos J.Z. and Buenger E.D. 2005. Carbon dynamics and sequestration in an irrigated Vertisol in Central Mexico. Soil and Tillage Research 83: 148-158.
Forouzeh, M.R., Heshmati, G.A., Mesbah, H. and Ghanbarian, G.A. 2008. Effect of floodwater irrigation on carbon sequestration potential of Helianthemum lippii (L.) Pers., Dendrostellera lessertii Van Tiegh. and Artemisia sieberi Besser in the Gareh Bygone plain: A case study. Pajouhesh Sazandegi (78):11-19. (in Persian with English Summary)

Gao, Y.H., Lue, P., Wu, C.H. and Wang, G.X. 2007. Grazing intensity impacts on carbon sequestration in an Alpine Meadow on the Eastern Tibetan Plateau. Journal Journal of Agricultural and Biological Science 3(6): 642-647.

Hajabbasi, M.A. and Hemmat, A. 2000. Tillage impacts on aggregate stability and crop productivity in a clay-loam soil in central Iran. Soil and Tillage Research 59: 205212.

Havlin, J.L., Kissel, D.E., Maddux, L.D., Claasen, M.M. and Long, J.H. 1990. Crop rotation and tillage effects on soil organic carbon and nitrogen. Soil Science Society of America Journal 54: 448-452.

Hill, M.J., Braaten, R. and McKeon, G.M. 2003. A scenario calculator for effects of grazing land management on carbon stocks in Australian rangelands. Environmental Modelling and Software 18(7): 627-644.

Hutchinson, J.J., Campbell, C.A. and Desjardins, R.L. 2007. Some perspectives on carbon sequestration in agriculture. Agriculture and Forest Meteorology 142: 288-302.

Ingram, J.S.I. and Fernandez, E.C.M. 2001. Managing carbon sequestration in soils: concepts and terminology. Agriculture, Ecosystems and Environment 87: 111-117.

Skowroñska, M., Filipek, T., 2014. Life cycle assessment of fertilizers: a review. Int. Agrophys. 28: 101-113

Yan Huimin, Cao Mingkui, Liu Jiyuan, Tao Bo, 2007. Potential and sustainability carbon sequentation with improved soil management in agricultural land of China. Agriculture, Ecosystem \& Environment 121(4): 325-335. 